\title{
Macroanatomic and Histological Examination of the Trachea and Syrinx in
}

\author{
Budgerigars and Canaries
}

\author{
Ozan GÜNDEMIR ${ }^{1, a,{ }^{*},}$, Hasan ALPAK ${ }^{1, b}$ \\ ${ }^{1}$ Istanbul University -Cerrahpasa, Faculty of Veterinary Medicine, Department of Anatomy, Avcılar, Istanbul, Turkey. \\ aORCID: 0000-0002-3637-8166, bORCID: 0000-0002-1129-971X
}

Geliş Tarihi: 28.11.2019

Kabul Tarihi: 05.06.2020

\begin{abstract}
The purpose of the present study is to examine and compare the trachea and larynx caudalis of budgerigars and canaries in a macroanatomic manner. 18 canaries and 29 budgerigars that were collected as dead from the clinics of the surrounding area were used in this study. The number of cartilago trachea was 46-47 in canaries; and 53-61 in budgerigars. Crossman's Triple Staining Method was used for histological examinations. $0.1 \%$ methylene blue solution was used to examine in a stereo microscope. Tracheobronchial-type syrinx was observed in both species. In canaries last 4-5 trachea rings were joined together to form the tympanum. It was observed that in all species the trachea rings were full. The ligamentum annulare and musculus trachealis were not observed in both species. While pessulus and tympanum were observed in canaries, they were not detected in budgerigars. Musculi syringeales was detected in budgerigars in an extremely developed structure. Cartilagines bronchosyringeales formed the last part of the syrinx; and it consisted 8-9 cartilages in canaries and 6-7 cartilages in budgerigars.
\end{abstract}

Keywords: Budgerigar, Canary, Syrinx, Trachea, Veterinary anatomy.

\section{Muhabbet Kuşları ve Kanaryalarda Trachea ve Syrinx'in Makroanatomik ve Histolojik Incelenmesi}

Özet: Bu çalışmanın amacı, muhabbet kuşları ve kanaryaların trachea ve larynx caudalis'ini karşılaştırmalı olarak makroanatomik incelemektir. Çevre kliniklerden ölü olarak toplanan 18 kanarya ve 29 muhabbet kuşu bu çalışmada kullanıldı. Cartilago trachealis sayısının kanaryalarda 46-47, muhabbet kuşlarında ise 53-61 olduğu görüldü. Histolojik incelemeler için Crossman üçlü boyama yöntemi kullanılmıştır. Stereo Mikroskopta incelemek içinse \% 0.1 metilen mavisi çözeltisi kullanılmıştır. Her iki türde de tracheobronchial tipte syrinx gözlendi. Trachea kıkırdaklarının tam bir halka şeklinde olduğu gözlendi. Ligamentum anulare ve musculus trachealis iki türde de görülmedi. Kanaryalarda pessulus ve tympanum görülürken, bu yapılara muhabbet kuşunda rastlanılmadı. Muhabbet kuşlarında ise oldukça gelişmiş yapıda musculi syringeales görüldü. Cartilagines bronchosyringeales'in syrinx'in son kısmını oluşturduğu görüldü; bu kısmı kanaryalarda 8-9 kıkırdak, muhabbet kuşlarında ise 6-7 kıkırdak meydana getirmişti.

Anahtar Kelimeler: Muhabbet kuşu, Kanarya, Syrinx, Soluk borusu, Veteriner anatomi.

\section{Introduction}

The trachea which is consistent of cartilagines tracheales, begins just under the larynx and runs down in the median line and goes through the ventral of the esophagus before entering the chest area between the furcula (Getty, 1975; Nickel, 1977; Mathey; 1965).

The number of cartilagines tracheales changes between 108 and 126 in birds and unlike mammals they are not in the shape of " $C$ ", each cartilage consists of a full ring (Getty, 1975). Musculus trachealis and ligamentum annulare do not exist in birds (Getty, 1975; Onuk et al., 2010). The diameter of the rings measured as $3 \mathrm{~mm}$ at the widest parts; and $2-2.5 \mathrm{~mm}$ in the narrowest parts. The initial part of the trachea is flattened dorso-ventrally, circular in the central part, and flattened on both sides at final parts (Getty, 1975).
Unlike mammals, larynx is divided into two parts as; larynx cranialis and larynx caudalis. In birds, while larynx cranialis acts as a respiratory system organ, larynx caudalis (syrinx) acts as a sound organ and positioned in the bifurcatio trachea area over the basis of the heart (Demirsoy, 1992; Getty, 1975; Nickel, 1977; Yılmaz et al., 2012; Yılmaz et al., 2016).

Three types of syrinxes are observed in birds. If only the cartilagines tracheales participate in the formation of the syrinx, tracheal syrinx is formed; if only the cartilagines bronchiales participate in the formation of the syrinx, bronchial syrinx is formed, and if they both participate, the tracheobronchialtype syrinx is formed (Baumel et al., 1993; Getty, 1975; King and Mclelland, 1984).

The last rings of the trachea are wider compared to the previous ones (Getty, 1975). These 
cartilages combine forming the tympanum. It was reported that 4 trachea rings form the tympanum in Denizli roosters, 3 in red hawks; 3 in ostriches, and 2 in geese (Kabak et al., 2007; Tasbas et al., 1994; Yıldız et al., 2005).

Pessulus is located at the end of the tympanum, consist of different structures that vary among species. It consists cartilage in chickens and quails, connective tissue in species such as pigeons (Bayram and Liman, 2000; Getty, 1975; King and Mclelland, 1984; Nickel et al., 1977; Yıldız et al., 2005). The pessulus does not exist in penguins, pelicans and loons (Griffiths, 1994; Tasbas et al., 1994).

In the bird a ligament called ligamentum interbronchiale is located between the bronchi after the bifurcatio area (Getty, 1975; King and Mclelland, 1984).

In the present study, the purpose was to demonstrate the morphological structures of the trachea and the syrinx, which is a sound organ, of canaries and budgerigars, known for their beautiful voices, and to make comparisons between these two species.

\section{Materials and methods}

18 canaries and 29 budgerigars bred in Turkey were used as the study materials. Dead birds were collected from various breeding establishments and private clinics in the area.

Four canaries and seven budgerigars were used for the histological study. The birds were dissected according to literature (Çalışlar, 1977) and the trachea and syrinx were removed. The organs were fixed in a buffer solution ( $10 \%$ formaldehyde) for three days. After fixation tissue sections were routinely processed and embedded in paraffin. 5micron $(\mu)$-thick sections were taken and stained with Crossman's Triple Staining Method (Crossman, 1937). The stained slides were photographed and measured with light microscope (Leica, EG 1160).

Fourteen canaries and twenty-two budgerigars were used for macro-anatomic examination studies. To prepare the cartilages of the trachea and syrinx for this examination, the materials were left in $70 \%$ alcohol for half an hour; and then submerged in $0.1 \%$ methylene blue solution for 15 minutes. Then, in order to remove excess methylene stain, they were kept in distilled water for one minute and then incubated in 50\%, 70\% and $90 \%$ alcohol, respectively. They were examined and photographed under stereomicroscope (Olympus, BX53F).

Ethical approval for the study was obtained from Istanbul University Ethical Board (2014/83).

Nomina Anatomica Avium was used as the basis for terminology (Baumel et al., 1993).

\section{Results}

In budgerigars 53-61 and in canary 46 and 47 cartilago trachea was determined in the trachea. In both species the trachea rings were in full-ring shape, and they were not associated with the trachea ring before or after them. It was determined that connective tissue fills the neighboring trachea rings. Ligamentum annulare and musculus trachealis were not detected in any of the species (Figure 1A).

A
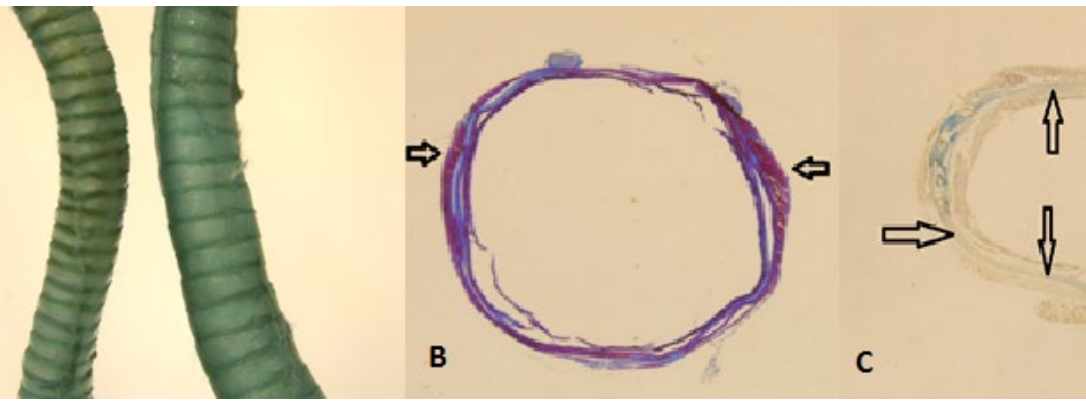

Figure 1: A: The image of the trachea under microscope (the trachea of the canary to the left; the trachea of the budgerigar to the right) (stereomicroscope), B: The image of the transversal section of the trachea in budgerigars; the tip of the arrow: musculus tracheolateralis (Crossman staining, 40x zoom) (light microscope), C: The tip of the arrow: The bone tissue in the cartilago trachealis (light microscope).

The rings were flattened in a dorso-ventral manner along all the progression of the trachea in budgerigars (Table 1). But in canaries, the last part of the trachea was found to be latero-lateral flattened.

The musculus tracheolateralis which provides the movement of trachea was observed in both species (Figure 1B). Histologically, in some samples in both species, the cartilage tissue was determined to metaplasia to bone tissue (Figure 1C).

Tracheobronchial-type syrinx was observed in both species. In canary last 4-5 cartilagines tracheosyringeales were joined together to form the tympanum (Figure 2A). In budgerigars, 
Table 1: The values of the width of the cartilage rings along the progression of the trachea in budgerigars and canaries.

\begin{tabular}{|c|c|c|c|c|c|c|}
\hline Matarial Number & DV & LL & DV & LL & DV & LL \\
\hline & \multicolumn{2}{|c|}{ Upper $1 / 3$} & \multicolumn{2}{|c|}{ Middle $1 / 3$} & \multicolumn{2}{|c|}{ Lower $1 / 3$} \\
\hline B1 & $1588 \mu$ & $1910 \mu$ & $1542 \mu$ & $1695 \mu$ & $1218 \mu$ & $1196 \mu$ \\
\hline B2 & $1617 \mu$ & $1701 \mu$ & $1414 \mu$ & $1691 \mu$ & $1120 \mu$ & $1278 \mu$ \\
\hline B3 & $1552 \mu$ & $1681 \mu$ & $1454 \mu$ & $1660 \mu$ & $1221 \mu$ & $1577 \mu$ \\
\hline B4 & $1403 \mu$ & $1773 \mu$ & $1278 \mu$ & $1569 \mu$ & $1372 \mu$ & $1392 \mu$ \\
\hline B5 & $1373 \mu$ & $1674 \mu$ & $1305 \mu$ & $1419 \mu$ & $1070 \mu$ & $1216 \mu$ \\
\hline B6 & $1285 \mu$ & $1793 \mu$ & $1218 \mu$ & $1462 \mu$ & $1032 \mu$ & $1031 \mu$ \\
\hline B7 & $1318 \mu$ & $1072 \mu$ & $1069 \mu$ & $1317 \mu$ & $1175 \mu$ & $1215 \mu$ \\
\hline C1 & $1191 \mu$ & $1605 \mu$ & $1221 \mu$ & $1750 \mu$ & $1854 \mu$ & $1181 \mu$ \\
\hline C2 & $1191 \mu$ & $1640 \mu$ & $1210 \mu$ & $1780 \mu$ & $1851 \mu$ & $1156 \mu$ \\
\hline C3 & $1140 \mu$ & $1595 \mu$ & $1163 \mu$ & $1745 \mu$ & $1819 \mu$ & $1222 \mu$ \\
\hline C4 & $1150 \mu$ & $1627 \mu$ & $1116 \mu$ & $1763 \mu$ & $1829 \mu$ & $1170 \mu$ \\
\hline
\end{tabular}

B: Budgerigars, C: Canaries, DV: Dorso-ventral, LL: Latero-lateral.

cartilagines tracheosyringeales were consisted of 9 or 10 cartilages; and there was no connection between these cartilages. Musculi syringeales wrapped the cartilagines tracheosyringeales in a strong manner (Figure 2B).

In canary significant pessulus were detected in the caudal area of the tympanum. This structure was not exist in budgerigars (Figure 2).
Cartilagines bronchosyringeales formed the last part of the syrinx; and it consisted 8-9 cartilages in canaries and 6-7 cartilages in budgerigars (Figure 2).

Musculi syringeales, muscle layer which wrapped the tympanum, was more developed in budgerigars then in canaries (Figure 2, Figure 3).

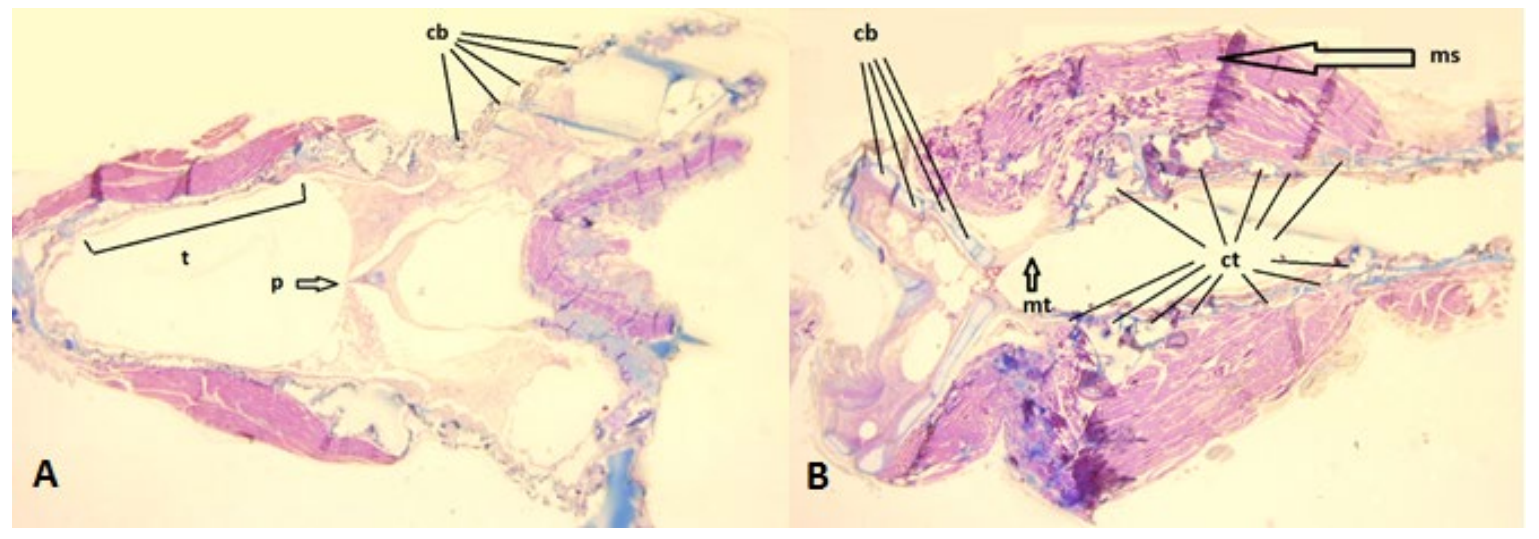

Figure 2: p: pessulus, t: tympanum, ct: cartilagines tracheosyringeales, $\mathrm{mt}$ : membrana tympaniformis, $\mathbf{m s :}$ musculi syringeales, cb: cartilagines bronchosyringeales (Crossman staining, 40x zoom), A: Canary, B: Budgerigar. (stereomicroscope).

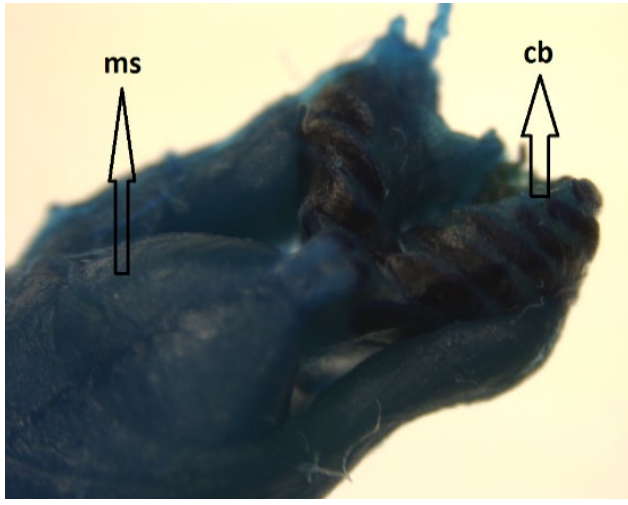

Figure 3: The dorsal view of the syrinx in budgerigars (stereomicroscope), ms: musculi syringeales, $c b$ : cartilagines bronchosyringeales.

\section{Discussion}

The canary (Serinus canaria) member of Fringillidae family is a cage bird famous with its beautiful sound. The budgerigar (Melopsittacus undulatus) is a domestic cage species which originates from Australia and member of Psittacidae family. Although both species are included in Passeriformes group, these two species differ from other birds in a morphologic manner (Demirsoy, 1992).

In the presented study, the number of cartilagines tracheales was determined to be between 53-61 in budgerigars; and 46-47 in canaries. This number presented to be varied 
between 137-140 in geese (Onuk et al., 2010); 112117 in Gerze rooster (Onuk et al., 2015); 53-57 in the Pica pica (Balkaya et al., 2016) and between 115 and 134 in seagulls (Gezer and Pazvant, 2010). In bird it has been reported that the number of the cartilagines trachealis is related with the length of the neck (Nickel et al., 1977).

In literature, the cartilagines trachealis of the birds were reported to be on top of each other (Cevik-Demirkan et al., 2007; Kabak et al., 2007; Mathey, 1965; Nickel et al., 1977; Onuk et al., 2010), yet in seagulls and geese this structure is reported to form letter " $\mathrm{H}$ " like structures as a result of fusion of the rings (Gezer and Pazvant, 2010; Onuk et al., 2010). In the presented study, this fusion was not determined in budgerigars and canaries. Each cartilago trachea was determined to form separate structures and there was only connective tissue between rings.

In birds tracheal rings are reported to be dorso-ventrally flat in the section following larynx cranialis, became more oval later, and flattened on both sides in the last section (Getty, 1975). In this study, it was determined that the cartilago of budgerigars were dorso-ventrally flat along the whole progression of the trachea. Latero-lateral diameter of the canaries was greater than the dorso-ventral diameter at the beginning and middle section of the trachea. However, the last part of the canaries was observed to be latero-lateral flattened.

In geese (Onuk et al., 2010), pigeons (Yıldız et al., 2005), seagulls (Gezer et al., 2012), ostriches (Yıldız et al., 2003), ducks (Frank et al., 2007) and in some domestic birds tracheobronchial-type syrinx was reported (Bayram and Liman, 2000; CevikDemirkan et al., 2007; Kabak et al., 2007; King, 1989). Similarly, in this study budgerigars and canaries presented to have tracheobronchial-type syrinx.

Tympanum is consistent of 3 or 4 cartilages in chickens, 4 in Denizli rooster, 2 in geese and Japanese quail and 3 in red hawk (Cevik-Demirkan et al., 2007; Getty, 1975; Kabak et al., 2007; Onuk et al., 2010; Tasbas et al., 1994). The tympanum was also detected in canaries and budgerigars, as mentioned in the literature before. The tympanum was consisting of the last 4-5 trachea rings in canaries and 9-10 rings in budgerigars; and some of the cartilage that formed the tympanum was ossified depending on age as in Denizli roosters, chickens, canaries and budgerigars (Cover, 1953; Getty, 1975; Tasbas et al., 1994).

The pessulus, which is located the caudal of the tympanum and involved in the formation of the sound is clearly visible in geese (Onuk et al., 2010), pigeons (King and Mclelland, 1984), chickens (Getty,
1975), ostriches (Yıldız et al., 2003), owls (Griffiths, 1994) and was significant in canaries. Like in loon, kiwi bird, black cormorant, pelican, penguin and in skylark (Griffiths, 1994; King and Mclelland, 1984; Tasbas et al., 1994) the pessulus was not detected in budgerigars. There was no difference between the membrane tympaniformis.

Cartilagines bronchosyringeales, which forms the lower part of the syrinx, is consist of 6 cartilage rings in geese (Onuk et al., 2010), 3 cartilage rings in Japanese quail and ostriches, and 4 cartilage rings in the crows (Cevik-Demirkan et al., 2007; Yıldız et al., 2003; Chamberlain et al., 1968). In the presented study the cartilagines bronchosyringeales was detrermined to form the last section of the syrinx, and was consisted of 8-9 cartilage in canaries, and 6-7 cartilage in budgerigars. It was reported that all birds have a well-developed pessulus. The most important finding of this study was the pessulus observed in canary does not exist in budgerigar. In addition, the syrinx muscles in budgerigars were much more developed than the canaries. By conducting other studies on different kinds of passeriformes that can imitate the human sound, these differences in the family of Psittacidae can be determined more detailed.

In conclusion, the trachea and larynx caudalis of budgerigars and canaries were examined in detail anatomically and histologically. The data obtained in the present study were compared with the respiratory system data of domestic birds reported in previous studies to show the differences and similarities.

\section{Acknowledgement}

The presented study is produced from the PhD thesis of Ozan Gündemir (Advisor Prof. Dr. Hasan ALPAK) "Comparative Evaluation of Canary and Budgerian Respiratory System with Morphology and Morphology" and supported by İstanbul University, Scientific Research Projects Unit (Project No: 49666).

\section{References}

Balkaya H, Ozudoğru Z, Ozdemir D, Erbas E, Kara H, 2016: Saksağanda (Pica pica) larynx ve trachea üzerinde anatomik ve histolojik bir çalışma. Harran Univ Vet Fak Derg, 5, 44-49.

Baumel JJ, King AS, Breazile JE, 1993: Nomina Anatomica Avium. Publications of The Nuttall Ornithological Club No:23, Cambridge.

Bayram G, Liman N, 2000: Bıldırcınlarda sirinks'in postnatal gelişimi üzerine morfolojik araştırmalar. Turk J Vet Anim Sci, 24, 381-392. 
Chamberlain DR, Gross WB, Cornwell GW, Mosby HS, 1968: Syringeal anatomy in the common crow. The Auk, 85, 244- 252.

Cover MS, 1953: Cross and microscopic anatomy of the respiratory system of the turkey. II. Larynx, trachea, syrinx, bronchi and lungs. Am J Vet Res, 14, 230-238.

Crossman G, 1937: A modification of Mallory's connective tissue stain with a discussion of the principles involved. Anat Rec, 69, 33-34.

Çalışlar T, 1977: Tavuk Diseksiyonu. Ankara Üniversitesi Basım Evi. Ankara, Türkiye 28-31.

Çevik-Demirkan A, Hazıroğlu RM, Kürtül i, 2007: Gross Morphological and Histological Features of Larynx, Trachea and Syrinx in Japanese Quail. Anat Histol Embryol, 36, 215-219.

Demirsoy A, 1992: Yaşamın temel kuralları, Omurgalılar (Sürüngenler, Kuşlar ve Memeliler) cilt III, Birinci baskı, Meteksan. Ankara.

Frank T, Probst A, König HE, Walter I, 2007: The syrinx of the male mallard (anas platyrhynchos) special anatomical features. Anat Histol Embryol, 36, 121126.

Getty R (1975): Sisson and Grossman's the Anatomy of the Domestic Animals, 5th edn, Vol. 1, 2. New York: W.B. Saunders Company.

Gezer Ince N, Pazvant G, 2010: Martılarda larynx ve trachea üzerinde makro-anatomik çalışma. Istanbul Univ Vet Fak Derg, 36, 1-6.

Gezer İnce N, Pazvant G, Alpak H, 2012: Anatomical features of the syrinx in sea gulls. Ankara Univ Vet Fak Derg, 59, 1-3.

Griffiths CS, 1994: Monophyly of the Falciformes based on syringeal morphology. The Auk, 111, 787-805.

Kabak M, Hazıroğlu RM, Orhan IO, 2007: The gross anatomy of larynx, trachea and syrinx in the longlegged buzzard (Buteo rufinus). Anat Histol Embryol, 36, 27-32.

King AS, 1989: Functional Anatomy of the Syrinx. In: Form and Function in Birds. pp. 105-182. Academic Press, London.

King AS, Mclelland J, 1984: Respiratory System. In: Birds their structure and function, Second ed., Bailiere Tindall, England, 110-144.
Mathey WJ, 1965: Avian tracheal rings. Poult Sci, 44, 1465-1467.

Nickel R, Schummer A, Seiferle E, 1977: Anatomy of the Domestic Birds. Verlg Paul Parey, Berlin- Hamburg, pp. $65-70$.

Onuk B, Hazıroğlu RM, Kabak M, 2010: The Gross anatomy of the larynx, trachea and syrinx in goose (Anser anser domesticus): Bronchi and sacci pneumatici. Kafkas Univ Vet Fak Derg, 16, 443-450.

Onuk B, Kabak M, Gülbahar MY, Kabak Y, Demirci B, Karayiğit M, Gültekin M, 2015: Gerze horoz ve tavuklarında larynx, trachea ve syrinx'in anatomik yapısının belirlenmesi. Istanbul Üniv Vet Fak Derg, 41, 92-98.

Taşbaş M, Hazıroğlu RM, Çakır A, 1994: Denizli horozunun solunum sisteminin morfolojisi II. Larynx, trachea, syrinx. Ankara Univ Vet Fak Derg, 41, 135-153.

Taşbaş M, Özcan Z, Hazıroğlu RM, 1986: Penguen dili ve ön solunum yollarının (larynx cranialis, trachea, syrinx) anatomik ve histolojik yapısı üzerinde bir çalışma. Ankara Univ Vet Fak Derg, 33, 240-261.

Yıldız B, Bahadır A, Akkoç A, 2003: A Study on the morphological structure of syrinx in ostriches (Struthio camelus). Anat Histol Embryol, 32, 187191.

Yıldız H, Yılmaz B, Arıcan I, 2005: Morphological structure of the syrinx in the Bursa roller pigeon (Columba livia). Bull Vet Inst Pulawy, 49, 323-327.

Yılmaz B, Demircioğlu i., Arıcan I, Yılmaz R, 2016: Aseel Irkı Horoz ve Tavuklarda Larynx, Trachea ve Syrinx'in Anatomik ve Histolojik Yapısı. Fırat Univ Sag Bil Vet Derg, 30(3), 211-216.

Yılmaz B, Yılmaz R, Arıcan I, Yıldız H, 2012: Anatomical Structure of the Syrinx in the Mallard (Anas platyrhynchos). Harran Unıv Vet Fak Derg,1(2), 111116.

*Corresponding author: Ozan GUNDEMIR, Istanbul University-Cerrahpasa, Faculty of Veterinary Medicine, Departmant of Anatomy, Avcilar, Istanbul, Turkey

e-mail: Ozan_gundemir@hotmail.com 